PLPB: Pendidikan Lingkungan dan Pembangunan Berkelanjutan

DOI: https://doi.org/10.21009/PLPB.172.03

DOI: 10.21009/PLPB

\title{
HUBUNGAN ANTARA PENGETAHUAN PELESTARIAN LINGKUNGAN DAN INTENSI SISWA TERHADAP OUTPUT SEKOLAH DENGAN PARTISIPASI SISWA DALAM KEBERSIHAN LINGKUNGAN
}

\section{SURVEI DI SMA NEGERI 1 KOTA DEPOK}

\author{
Suhardjo \\ Dosen Pendidikan Geografi Universitas Negeri Jakarta \\ e- mail : mr_suhardjo@Yahoo.com
}

\begin{abstract}
The objective of this research is to analuyze the relationship of knowledge and enviromental conservation intention output of school students with students participation in the clean enviroment. The methode used was a survey and correlational techniques in One Senior High School, Depok.. The sampel of this research were 70 students wich proporsional random sampling. The results showed as follow: (1) The relationship between the Environmental Protection Knowledge with Students Participation in Environmental Hygiene showed a negative relationship. (2) The relationship between the intentions of the Output School Students with Student Participation in Environmental Hygiene showed a positive relationship. (3) The relationship between knowledge and intention of Environmental Protection against Output School Students together with Student Participation in Environmental Hygiene showed a positive relationship. From the research, the conclusion is that most of the students were able to understand the concepts, facts and procedures related to conservation of the environment, so most students have a strong intention to academic and non-academic.
\end{abstract}

Keywords: knowledge and intention of Environmental Protection, participation, environmental hygiene.

\begin{tabular}{|l|l|l|l|}
\hline Volume XVII & Nomor 02 & September 2016 & ISSN 1411-1829 \\
\hline
\end{tabular}




\section{PENDAHULUAN}

Permasalahan lingkungan hidup dewasa ini banyak dibicarakan orang, karena telah tampak adanya gejala dan kecenderungan pencemaran lingkungan yang diakibatkan oleh perbuatan manusia. Misalnya penggundulan hutan yang mengakibatkan erosi, polusi udara, pencemaran sumber daya air dan sungai sebagai akibat dari pembuangan limbah industri dan limbah rumah tangga, serta banyak kasus lain yang sekarang sudah menjadi fenomena umum.

Banyak faktor yang menjadi penyebab menurunnya kualitas lingkungan, diantaranya yaitu rendahnya tingkat pendidikan dan pengetahuan masyarakat tentang lingkungan, sehingga mereka kurang respon untuk dapat menerima informasi yang bermanfaat bagi dirinya. Di samping itu, kebiasaan hidup masyarakat yang selalu membuang sampah di sembarangan tempat, sulit untuk diubah dan ketidakpedulian terhadap lingkungan yang mengakibatkan lingkungan menjadi kotor dan tercemar.

Pencemaran lingkungan umumnya disebabkan oleh masyarakat di lingkungannya itu sendiri. Sebagai salah satu contoh, yaitu kurang baiknya pengetahuan tentang lingkungan bagi siswa, dapat mempengaruhi perilaku mereka dalam pemeliharaan kebersihan lingkungan, sehingga tindakannya berakibat negatif terhadap lingkungan. Misalnya sampah ditumpuk begitu saja, dapat mengakibatkan terjadinya tempat sarang nyamuk dan ini sebagai akibat dari kurangnya pengetahuan terhadap pengaruh bahaya sampah maupun limbah.

Menciptakan lingkungan yang bersih dan sehat adalah tanggung jawab bersama, khususnya para pemimpin dan masyarakat yang ada di sekitar lingkungannya. Mereka memiliki peran yang penting dalam menjaga lingkungan serta menciptakan budaya lingkungan yang bersih dan sehat.

Berdasarkan paradigma sehat ditetapkan visi Indonesia Sehat 2010, dimana ada 3 pilar yang perlu mendapat perhatian khusus, yaitu lingkungan sehat, perilaku sehat dan pelayanan kesehatan yang bermutu, adil dan merata. Untuk perilaku sehatbentuk konkritnya yaitu perilaku proaktif memelihara dan meningkatkan kesehatan. mencegah risiko terjadinya penyakit, melindungi diri dari ancaman penyakit serta berpartisipasi aktif dalam upaya kesehatan.

Dalam mewujudkan visi Indonesia Sehat 2010 telah ditetapkan misi pembangunan yaitu menggerakkan 
pembangunan nasional berwawasan kesehatan. Mendorong kemandirian masyarakat untuk hidup sehat, memelihara dan meningkatkan pelayanan kesehatan yang bermutu, merata dan terjangkau, serta memelihara dan meningkatkan kesehatan individu, keluarga dan masyarakat beserta lingkungannya.

Untuk melaksanakan misi pembangunan kesehatan diperlukan upaya diantaranya bagaimana menjaga dan memelihara kebersihan di lingkungan sekolah. Kebersihan sekolah merupakan kewajiban bersama antara guru, siswa, karyawan, dan semua unsur yang ada di dalamnya. Akan tetapi kebisaaan yang terjadi adalah kebersihan sekolah tersebut dibebankan kepada penjaga sekolah. Hal ini merupakan contoh yang kurang baik dalam pelaksanaan pendidikan khususnya di sekolah.

Upaya pengelolaan lingkungan hidup sudah menjadi tugas dan kewajiban kita bersama. Seperti lingkungan tempat tinggal adalah menjadi tugas bagi semua warga yang tinggal dan menetap di sekitar lingkungan tersebut, tidak berbeda juga kebersihan lingkungan sekolah, maka kewajiban menjaga dan mengelola lingkungan hidup di sekolah adalah semua komponen sekolah, yaitu guru atau pendidik, siswa atau peserta didik, karyawan, petugas kebersihan, sehingga pada akhirnya tercipta lingkungan sekolah yang bersih, sehat dan nyaman.

Kebersihan sekolah walaupun sudah diprogramkan dalam institusi sekolah namun banyak sekolah yang masih kotor dan terkesan kurang nyaman untuk belajar mengajar. Hal ini dikarenakan belum dilakukannya upaya kebersihan sekolah oleh seluruh komponen yang ada didalam sekolah, yaitu pendidik, peserta didik, karyawan, ataupun petugas kebersihan.

Manusia dan lingkungan hidup merupakan suatu kesatuan yang tidak dapat dipisahkan. Manusia dengan daya yang dimilikinya dapat mempengaruhi kondisi lingkungan hidup dan begitu pula sebaliknya lingkungan hidup dapat mempengaruhi manusia. Lingkungan hidup menurut Undang-Undang No. 32 Tahun 2009 adalah kesatuan ruang dengan semua benda, daya, keadaan, dan makhluk hidup termasuk manusia dan perilakunya, yang mempengaruhi kelangsungan perikehidupan dan kesejahteraan manusia serta makhluk hidup lain(UU RI No 32 Tahun 2009 tentang perlindungan dan Pengelolaan Lingkungan Hidup : 3).

Di Indonesia bentuk dan jenis menurunnya kualitas dan kerusakan lingkungan sudah sedemikian beragam, 
bahkan sampai pada taraf yang mengkhawatirkan.

Misalnya

penggundulan hutan, tanah kritis, pencemaran di darat, udara, sungai, abrasi, dan intrusi air laut. Dalam perkembangannya hingga sekarang tampaknya penurunan kualitas lingkungan dan kerusakan lingkungan bukan berkurang melainkan semakin parah dan membahayakan kehidupan. Oleh karena itu, penurunan mutu lingkungan dan peningkatan kerusakan lingkungan harus segera ditanggulangi.

Kerusakan kualitas lingkungan disebabkan terutama oleh sistem pendidikan yang tidak memperhatikan masalah lingkungan (Putrawan,1990: 89) Berkaitan dengan hal itu, upaya yang strategis dan mendasar yang perlu dilakukan adalah mengubah paradigma masyarakat dalam memandang lingkungan tersebut, yang sebelumnya tidak pro dengan lingkungan ke arah yang pro dengan lingkungan.

Upaya yang tepat dalam memandang lingkungan adalah melalui pendidikan. Pendidikan menurut Undang-undang Repubilk Indonesia nomor 20 tahun 2003 Bab VI pasal 13, menyatakan: “ pendidikan adalah usaha sadar dan terencana untuk mewujudkan suasana belajar dan proses pembelajaran agar peserta didik secara aktif mengembangkan potensi dirinya untuk memiliki kekuatan spiritual keagamaan, pengendalian diri, kepribadian, kecedasan, akhlak mulia, serta keterampilan yang diperlukan dirinya, masyarakat, bangsa dan negara" (UU RI nomor 20 tahun 2003, bab VI pasal 13). Tujuan pendidikan pada hakikatnya yang paling azasi merupakan upaya pembentukan kepribadian manusia yang mengacu pada nilai-nilai tertentu. Pendidikan lingkungan merupakan suatu usaha untuk mengubah perilaku dan sikap masyarakat, dengan tujuan meningkatkan pengetahuan, ketrampilan dan kesadaran akan masalah lingkungan. Karena itu dukungan sepenuhnya darimanajemen sekolah memberikan kontribusi dalam meningkatkan kesadaran dan kreativitas siswa.

Hingga kini pendidikan di Indonesia masih berorientasi pada mencetak prestasi siswa di bidang akademik, belum mempraktikkan dan mengembangkan pendidikan berbasis lingkungan hidup dan keterampilan berwirausaha. Pendidikan Lingkungan Hidup (PLH) yang diharapkan sebagai wahana bagi pembinaan perubahan paradigma dalam pembentukan perilaku lingkungan bertanggung jawab masih menghadapi beberapa kendala. Kendala tersebut antara lain, masih terdapat 
pemahaman tentang makna pendidikan yakni masih sebatas "transfer of konwledge", sehingga penguasaan materi masih merupakan hal yang penting dibandingkan dengan perubahan sikap apalagi perubahan perilaku.

Pendidikan lingkungan hidup merupakan pembelajaran yang dilakukan untuk membantu peserta didik dalam memahami lingkungan hidup dengan tujuan akhir untuk meningkatkan perlindungan dan sikap bertanggung jawab terhadap lingkungan hidup. Bagaimanapun pendekatan yang digunakan dalam pembelajaran lingkungan hidup seyogyanya dapat menghantarkan anak didik memiliki sikap, nilai serta perilaku yang bertanggung jawab terhadap lingkungannya. Dengan demikian, jika hal itu terjadi niscaya lingkungan akan memberikan manfaat tidak hanya bagi generasi kini semata melainkan juga bagi generasi yang akan datang.

Pendidikan tentang lingkungan hidup terutama pada siswa di SMA terdapat dalam mata pelajaran Geografi kelas XI IPS semester genap yaitu pada standar kompetensi menganalisis pemanfaatan dan pelestarian lingkungan hidup, dengan dua kompetensi dasar:
(1) mendeskripsikan pemanfaatan lingkungan hidup dalam kaitannya dengan pembangunan berkelanjutan; (2) menganlisis pelestarian lingkungan hidup dalam kaitannya dengan pembangunan berkelanjutan (Kurikulum SMA 2004). Sehingga dengan target pencapaian dalam standarkompetensi dan kompetensi tersebut di atas diharapkan siswa memiliki pengetahuan tentang lingkungan, pembangunan berkelanjutan, dan pelestarian lingkungan.

Lingkungan keluarga, lingkungan rumah atau lingkungan tempat tinggal merupakan lingkungan pendidikan yang paling utama dan pertama bagi siapapun juga. Lingkungan tersebut memberi pengaruh pada masing-masing individu. Pembentukan sikap pada individu juga tidak luput dari pengaruh lingkungan, terutama lingkungan keluarga dan lingkungan tempat tinggal. Lingkungan keluarga merupakan sumber yang paling kuat dan lebih nyata dalam pembentukan sikap anak.

Jadi lingkungan di sekitar individu merupakan suatu penyebab atau kekuatan yang ada di luar individu dan yang akan mempengaruhi sikap individu tersebut. Hal tersebut dapat terjadi, sebab antara individu dengan 
lingkungannya terjadi proses saling mempengaruhi dan dipengaruhi secara timbal balik, dalam arti manusia mempengaruhi dan dipengaruhi lingkungannya.

SMA Negeri I merupakan salah satu SMA unggulan di wilayah Kota Depok dan termasuk kelompok SMA terbaik di Provinsi Jawa Barat. Sekolah ini terletak di jalan Raya Nusantara No 317 Depok pada kawasan pusat Kota Depok (Profil Kota Depok, 2008).

Program kebersihan lingkungan sekolah telah diterapkan, terlihat dari segi kerapihan dan keindahan lingkungan sekolahnya. Selain itu sekolah ini menuju sekolah yang bersih dan hijau (Green and Clean School). Beragam kegiatan yang dilakukan dalam ikut merealisasikan hal tersebut, para siswa dilibatkan diantaranya adalah lomba kebersihan, lomba karya tulis lingkungan, dan lomba pengolahan limbah.

Dimyati dan Mujiono (1994: 91) mengemukakan bahwa sekolah yang indah, pergaulan siswa yang rukun, akan memperkuat motivasi belajar. Kalau hal ini dikaitkan dengan kondisi kebersihan dan kesehatan lingkungan sekolah, maka kondisi kebersihan dan kesehatan lingkungan sekolah akan sangat mempengaruhi motivasi belajar siswa, sehingga dapat disimpulkan bahwa kondisi lingkungan yang sehat, kerukunan hidup dan ketertiban dalam pergaulan yang ditingkatkan dengan mutunya, lingkungan yang aman, tenteram, tertib, dan indah, maka semangat dan motivasi belajar akan mudah untuk diperkuat atau ditingkatkan.

Upaya menjaga kebersihan dan kesehatan lingkungan harus senantiasa ditanamkan mulai dari sejak dini. Terlebih lagi dalam lingkungan sekolah, pendidikan tentang kesehatan lingkungan, kebersihan diri, dan kesehatan sangat perlu ditanamkan dan dipraktekkan kepada dan oleh siswa dimasing-masing sekolah. Sehingga akhirnya akan menjadi sebuah kebisaaan atau budaya yang akan mampu menumbuhkan kesadaran untuk berpartisipasi dan berperan serta secara aktif dalam pengelolaan kebersihan lingkungan sekitarnya dimana dia tinggal dan khususnya di sekolah.

Pemberian materi yang berhubungan dengan upaya menjaga kebersihan dan kesehatan lingkungan terhadap siswa di sekolah diharapkan akan tumbuh kesadaran siswa terhadap tanggung jawab menjaga kesehatan dan kebersihan lingkungan, dan akhirnya siswa akan menjalankan dan melaksanakan hidup sehat dan bersih. Dengan memberikan materi tersebut, 
diharapkan siswa melaksanakan pola hidup bersih dan sehat sehingga dalam kehidupan sehari-hari dia akan selalu memelihara kebersihan lingkungan, kebersihan diri, dan kebersihan makanan. Pendidikan lingkungan hidup yang dilaksanakan oleh sekolah-sekolah seharusnya mampu menjadikan siswa untuk ikut menjaga dan melaksanakan kebersihan di lingkungan sekolah.

Sekolah sebagai tempat mendidik anak dapat dipakai sebagai agen pembaharuan masyarakat dan harapan bangsa, khususnya yang berkenaan dengan masalah lingkungan hidup, sehingga kelak anak-anak yang menjadi penerus mampu melaksanakan pembaharuan masyarakat dan bangsa tanpa menimbulkan kerawanan sosial.

Dalam proses pembelajaran banyak faktor yang mempengaruhi prestasi siswa. Salah satunya yaitu kebersihan lingkungan sekolah, khususnya pada lingkungan kelas. Kebersihan sangat mempengaruhi konsentrasi belajar siswa. Jika kelas bersih, indah dan tertata rapi maka kemungkinan besar kenyamanan dalam proses pembelajaran akan tercapai. dan pada gilirannya siswa bisa meningkatkan prestasinya, baik dalam bidang akademik maupun dalam bidang nonakademik.
Berdasarkan latar belakang masalah tersebut maka maslahnya dapat dirumuskan sebagai berikut: (1) apakah ada hubungan antara pengetahuan pelestarian lingkungan dengan partisipasi siswa dalam kebersihan lingkungan sekolah, (2) apakah ada hubungan antara intensi siswa terhadap output sekolah dengan partisipasi siswa dalam kebersihan lingkungan sekolah, dan (3) apakah ada hubungan antara pengetahuan pelestarian lingkungan dan intensi siswa terhadap output sekolah secara bersama-sama dengan partisipasi siswa dalam kebersihan lingkungan sekolah

\section{METODOLOGI PENELITIAN}

Tujuan penelitian ini adalah untuk mengungkap atau menguji apakah ada hubungan antara (1) pengetahuan pelestarian lingkungan dengan partisipasi siswa terhadap kebersihan lingkungan, (2) intensi siswa terhadap output sekolah dengan partisipasi siswa dalam kebersihan lingkungan, dan (3) pengetahuan pelestarian lingkungan dan intensi siswa terhadap output sekolah secara bersama-sama dengan partisipasi siswa dalam kebersihan lingkungan.

Metode yang digunakan dalam penelitian ini adalah metode survei 
dengan teknik korelasional. Penelitian ini dilakukan di SMA Negeri 1 Kota Depok dengan sampel sejumlah 70 siswa. Teknik pengambilan sampel dilakukan dilakukan secara proporsional random sampling. Sedangkan teknik analisis data menggunakan korelasi dan regresi sederhana melalui program SPSS 17,0.

\section{HASIL PENELITIAN DAN PEMBAHASAN}

\section{Pengetahuan}

Pelestarian

\section{Lingkungan.}

Secara umum dari deskripsi data, penguasaan pengetahuan pelestarian lingkungan siswa SMA Negeri 1 Kota Depok tinggi yaitu dengan skor 1705 atau sebesar 80,00 \%. Hal ini dimungkinkan karena mereka lebih dekat dengan situasi dan kondisi lingkungan kota Depok yang mendukung sebagai sumber belajar tentang pelestarian lingkungan hidup. Hal tersebut penyebabnya adalah, pertama bahwa sumber belajar yang berupa lingkungan sekitar walaupun tidak digunakan dalam kegiatan pembelajaran, namun secara tidak langsung telah memberikan pengalaman kepada siswa tersebut. Kota Depok sebagai kota penyangga DKI Jakarta yang sarat dengan pertumbuhan kotanya berdampak pada diantaranya kemacetan lalu lintas. Siswa terbiasa dengan pemandangan kemacetan lalu lintas yang menimbulkan polusi udara, pemborosan bahan bakar dan lainnya. Sehingga hal tersebut menumbuhkan rasa ingin tahu siswa terhadap permasalahan lingkungan. Kedua : Lokasi SMA negeri 1 terletak di pusat kota tentunya sangat memudahkan Guru dalam memberikan contoh-contoh tentang kerusakan lingkungan seperti polusi udara, pencemaran air dan juga pemanasan global. Contoh lainnya yang bisa dijelaskan oleh Guru dalam pelestarian lingkungan, misalnya:Car free day, Taman Kota, Ruang Terbuka Hijau (RTH), dan ada kebijakan Walikota Depok tentang satu hari tanpa nasi. Ketiga : kemudahan mereka dalam mengakses informasi terkait dengan materi lingkungan hidup seperti dari : Internet, televisi, koran, Jurnal maupun perpustakaan.

Pendidikan tentang lingkungan hidup secara langsung ada dalam mata pelajaran Geografi, karena mata pelajaran Geografi adalah ilmu yang menjadikan alam sebagai sumber belajar. Kondisi alam yang mendukung akan memudahkan dalam hal pembelajaran, bahkan pada materimateri tertentu alam sebagai sumber belajar sangat berperan penting. 
Berikut ini adalah sebaran skoring dari Pengetahuan Siswa tentang Pelestarian Lingkungan. Jika responden menjawab Benar diberi skor 1 dan jika responden menjawab salah diberi skor 0 (nol).

Tabel 1. Skor Pengetahuan Siswa tentang Pelestarian Lingkungan

\begin{tabular}{|c|c|c|c|c|c|c|c|c|}
\hline \multirow[t]{3}{*}{ No } & \multirow{3}{*}{ Indikator } & \multicolumn{5}{|c|}{ Frekuensi dan Skor } & \multirow{2}{*}{\multicolumn{2}{|c|}{ Skor Total }} \\
\hline & & \multicolumn{2}{|c|}{ Pemanfaatan } & \multicolumn{2}{|c|}{ Pemeliharaan } & \multirow{2}{*}{$\begin{array}{l}\text { Pengawasan } \\
\mathrm{F}\end{array}$} & & \\
\hline & & $\mathrm{F}$ & Skor & $\mathrm{F}$ & Skor & & Skor & \\
\hline 1 & Fakta & $\begin{array}{l}\mathrm{B}=179 \\
\mathrm{~S}=31\end{array}$ & \begin{tabular}{|l|l|}
179 \\
\end{tabular} & $\begin{array}{l}B=163 \\
S=47\end{array}$ & 163 & $\begin{array}{l}\mathrm{B}=228 \\
\mathrm{~S}=52\end{array}$ & 2228 & 570 \\
\hline 2 & Konsep & $\begin{array}{l}B=230 \\
S=50\end{array}$ & 230 & $\begin{array}{l}\mathrm{B}=225 \\
\mathrm{~S}=55\end{array}$ & 225 & $\begin{array}{l}\mathrm{B}=222 \\
\mathrm{~S}=58\end{array}$ & 222 & 677 \\
\hline$\beta$ & $\begin{array}{l}\text { Prosedur } \\
\text { al }\end{array}$ & $\begin{array}{l}B=171 \\
S=39\end{array}$ & 171 & $\begin{array}{l}\mathrm{B}=49 \\
\mathrm{~S}=21\end{array}$ & 49 & $\begin{array}{l}B=238 \\
S=42\end{array}$ & 238 & 458 \\
\hline
\end{tabular}

Berdasarkan tabel tersebut diatas dengan skor total 1705, maka pencapaian pengetahuan siswa tentang pelestarian lingkungan sesuai dengan jawaban responden yang benar dapat disimpulkan bahwa sebesar 81,19\% siswa memiliki pengetahuan tentang pelestarian lingkungan. Dan sisanya sebesar $18,81 \%$ responden menjawab salah.

Dari $81,19 \%$ siswa yang benar menjawab maka dapat dirinci hal-hal sebagai berikut : (1) Pada indikator fakta tentang pemanfaatan, pemeliharaan dan pengawasan terhadap pelestarian lingkungan, responden memiliki nilai sebesar 33,43 \%, (2) pada indikator konsep tentang pemanfaatan, pemeliharaan dan pengawasan terhadap pelestarian lingkungan, responden memiliki nilai sebesar 39,71\%, dan (3) pada indikator prosedural tentang pemanfaatan, pemeliharaan dan pengawasan terhadap pelestarian lingkungan, responden memiliki nilai sebesar $26,86 \%$.

Berdasarkan rincian tersebut, maka dapat disimpulkan bahwa siswa secara umum memiliki konsep tentang pemanfaatan, pemeliharaan, dan pengawasan tentang pengetahuan pelestarian lingkungan lebih tinggi dibandingkan dengan indikatorindikator lainnya. Hal tersebut tentunya terkait dengan kemampuan siswa dalam mempelajari ilmu geografi khususnya tentang topik lingkungan hidup sangat menarik, demikian pula peran guru yang lebih profesional dalam mengajar serta kemudahan-kemudahan dalam mengakses pembelajaran geografi.

Pada aspek pemanfaatan, pemeliharaan, dan pengawasan, persentase yang tinggi adalah pada aspek pengawasan sebesar 40,35\% kemudian selanjutnya adalah aspek pemanfaatan sebesar 34,02\% dan aspek pemeliharaan sebesar 25,63\%.

\section{Intensi Siswa terhadap Output Sekolah \\ SMA Negeri 1 sebagai salah satu} SMA unggulan di wilayah Kota Depok 
memang memiliki berbagai keunggulan baik dalam bidang akademik maupun non akademik. Hal tersebut telah dibuktikan dengan banyaknya kejuaraan yang diraihnya, baik dalam tingkat kota, provinsi, nasional maupun olympiade.

Salah satu dari faktor-faktor tersebut antara lain adalah adanya Niat (intensi) para siswa dalam meningkatkan mutu pendidikan sesuai dengan visi dan misi dari sekolah tersebut. Berdasarkan jawaban responden, $50 \%$ lebih siswa memiliki niat yang kuat dalam mewujudkan potensi akademik maupun non akademiknya. Fakta di lapangan menunjukkan bahwa ketiga aspek Intensi yaitu : sikap terhadap niat, fasilitas terhadap niat dan dukungan terhadap niat memiliki persentase secara berturut -turut yaitu sebagai berikut.

Tabel 2. Skor Intensi Siswa terhadap Output Sekolah (Pertanyaan Positif)

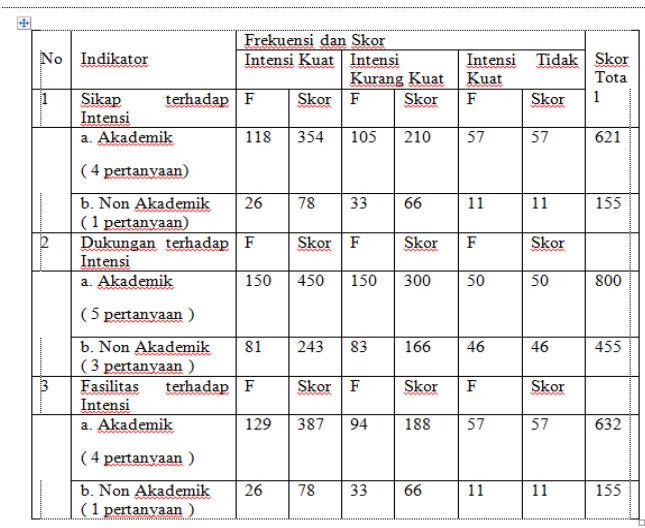

Berdasarkan pada tabel tersebut diatas maka indikator sikap terhadap intensi pada aspek akademik memiliki intensi yang kuat yaitu sebesar $57 \%$, kurang kuat sebesar 33,82 \%, dan tidak kuat sebesar 9,18\%. Artinya sikap terhadap intensi akademik sebagian besar siswa memiliki intensi yang kuat untuk dapat meningkatkan upaya prestasinya baik di bidang kegiatan keilmuan maupun prestasi belajar. Dan hanya sebagian kecil siswa tidak kuat untuk lebih meningkatkan kegiatan prestasi akademiknya.

Pada aspek non-akademik, siswa memiliki intensi yang kuat sebesar $50,32 \%$, kurang kuat sebesar 42,58 \%, dan tidak kuat sebesar 7,10 \%. Artinya bahwa sikap terhadap intensi nonakademik sebagian besar siswa memiliki intensi yang kuat untuk membangun sebuah kepribadian siswa yang baik seperti kejujuran, kerjasama, toleransi dan rasa peduli terhadap sesama warga sekolah. Dan hanya sebagian kecil siswa tidak kuat untuk membangun kepribadian dirinya.

Berikutnya adalah indikator dukungan terhadap intensi pada aspek akademik memiliki intensi yang kuat yaitu sebesar56,25 \%,kurang kuat sebesar 37,50 \%,dan tidak kuat sebesar 6,25 \%.Artinya dukungan terhadap intensi akademik sebagian besar siswa 
memiliki intensi yang kuat untuk dapat meningkatkan upaya prestasinya baik di bidang kegiatan keilmuan maupun prestasi belajar. Dukungan tersebut baik dari Orang tuanya, bapak dan Ibu Gurunya maupun Kepala Sekolah dan bahkan teman-teman satu kelompoknya dalam belajar. Selanjutnya hanya sebagian kecil siswa tidak kuat untuk mendapatkan dukungan dalam meningjkatkan kegiatan prestasi akademiknya. Misalnya orang tua tidak mendukung karena faktor biaya maupun ketidak ikut sertaan siswa tersebut dalam upaya meningkatkan prestasi akademiknya.

Selanjutnya pada aspek non akademik, siswa memiliki intensi yang kuat sebesar 53,40 \%, kurang kuat sebesar 36,49 \%, dan tidak kuat sebesar $10,11 \%$. Artinya bahwa dukungan terhadap intensi non akademik sebagian besar siswa memiliki intensi yang kuat untuk membangun sebuah kepribadian siswa yang baik seperti kejujuran, kerjasama, toleransi dan rasa peduli terhadap sesama warga sekolah. Dan hanya sebagian kecil siswa tidak kuat untuk membangun kepribadian dirinya. Dukungan terbesar datang dari orang tuanya kemudian adalah temantemannya.

Sementara itu pada indikator fasilitas terhadap intensi akademik menunjukkan intensi siswa yang kuat sebesar 61,23 \%, Intensi kurang kuat sebesar 29,74 \% dan intensi tidak kuat $9,01 \%$. Dari gambaran tersebut dapat dijelaskan bahwa sebagian besar siswa mendapatkan les tambahan dari orang tuanya dan orang tua memfasilitasi serta sekolah menyediakan akses terhadap peningkatan prestasi akademik siswa. Dan hanya sebagian kecil siswa memiliki intensi yang tidak kuat terhadap prestasi akademik.

Sedangkan pada indikator fasilitas terhadap intensi non-akademik menunjukkan intensi siswa yang kuat sebesar 50,32 \%, Intensi kurang kuat sebesar 42,58 \% dan intensi tidak kuat $7,10 \%$. Dari sebaran persentase tersebut maka dapat dijelaskan bahwa sebagian besar siswa memiliki intensi yang kuat terhadap fasilitas seperti penyediaan tempat sampah, menyiapkan alat-alat kebersihan, persiapan untuk kegiatan kerokhanian, menyiapkan kunjungan ke sesama teman jika terjadi musibah atau sakit.

Tabel 3. Intensi Siswa terhadap Output Sekolah (Pertanyaan Negatif)

\begin{tabular}{|l|l|l|l|}
\hline Volume XVII & Nomor 02 & September 2016 & ISSN 1411-1829 \\
\hline
\end{tabular}




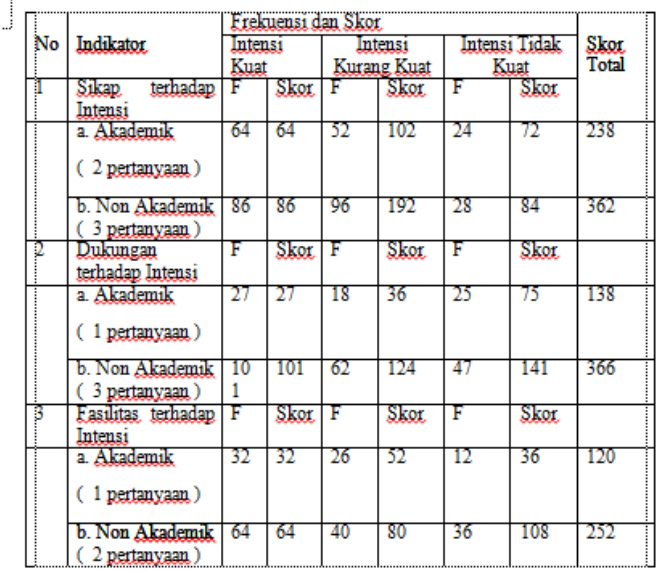

Berdasarkan tabel tersebut di atas, pada aspek sikap terhadap niat sebagian kecil memiliki kekuatan untuk tindakan tidak melakukan kegiatan akademik yaitu sebesar 26,89 \%, kurang kuat $42,86 \%$, dan tidak kuat 30,25\%. Maksudnya adalah bahwa siswa mempunyai kecenderungan yang kuat untuk melakukan tindakan kegiatan akademik.

Selanjutnya pada aspek kegiatan non-akademik siswa memiliki intensi yang kuat sebesar 23,76\%, kurang kuat sebesar 53,04 \%, dan tidak kuat sebesar $23,20 \%$. Artinya bahwa sikap terhadap intensi non akademik sebagian besar siswa memiliki intensi yang kuat untuk membangun sebuah kepribadian siswa yang baik seperti kejujuran, kerjasama, toleransi dan rasa peduli terhadap sesama warga sekolah. Dan hanya sebagian kecil siswa tidak kuat untuk membangun kepribadian dirinya.
Berikutnya adalah indikator dukungan terhadap intensi pada aspek akademik memiliki intensi yang kuat yaitu sebesar19,36 \%,kurang kuat sebesar 26,09\%,dan tidak kuat sebesar $54,35 \%$.Artinya dukungan terhadap intensi akademik sebagian besar siswa memiliki intensi yang kuat untuk dapat meningkatkan upaya prestasinya baik di bidang kegiatan keilmuan maupun prestasi belajar. Dukungan tersebut baik dari Orang tuanya, bapak dan Ibu Gurunya maupun Kepala Sekolah dan bahkan teman-teman satu kelompoknya dalam belajar. Selanjutnya hanya sebagian kecil siswa tidak kuat untuk mendapatkan dukungan dalam meningjkatkan kegiatan prestasi akademiknya. Misalnya orang tua tidak mendukung karena faktor biaya maupun ketidak ikut sertaan siswa tersebut dalam upaya meningkatkan prestasi akademiknya.

Selanjutnya pada aspek nonakademik, siswa memiliki intensi yang kuat sebesar 27,60 \%, kurang kuat sebesar 33,88\%, dan tidak kuat sebesar $38,52 \%$. Artinya bahwa dukungan terhadap intensi non-akademik sebagian besar siswa memiliki intensi yang kuat untuk membangun sebuah kepribadian siswa yang baik seperti kejujuran, kerjasama, toleransi dan rasa peduli terhadap sesama warga sekolah. Dan 
hanya sebagian kecil siswa tidak kuat untuk membangun kepribadian dirinya. Dukungan terbesar datang dari orang tuanya kemudian adalah temantemannya.

Sementara itu pada indikator fasilitas terhadap intensi akademik menunjukkan intensi siswa yang kuat sebesar 26,67 \%, Intensi kurang kuat sebesar 43,33\% dan intensi tidak kuat $30,00 \%$. Dari gambaran tersebut dapat dijelaskan bahwa sebagian besar siswa mendapatkan les tambahan dari orang tuanya dan orang tua memfasilitasi serta sekolah menyediakan akses terhadap peningkatan prestasi akademik siswa. Dan hanya sebagian kecil siswa memiliki intensi yang tidak kuat terhadap prestasi akademik.

Sedangkan pada indikator fasilitas terhadap intensi non-akademik menunjukkan intensi siswa yang kuat sebesar 25,39 \%, Intensi kurang kuat sebesar $31,75 \%$ dan intensi tidak kuat $42,86 \%$. Dari sebaran persentase tersebut maka dapat dijelaskan bahwa sebagian besar siswa memiliki intensi yang kuat terhadap fasilitas seperti penyediaan tempat sampah, menyiapkan alat-alat kebersihan, persiapan untuk kegiatan kerokhanian, menyiapkan kunjungan ke sesama teman jika terjadi musibah atau sakit.
3. Partisipasi Siswa dalam Kebersihan Lingkungan

Dalam rangka mewujudkan SMA negeri 1 kota Depok menuju Clean and Green School, berbagai upaya dan kebijakan telah diterapkan artinya seluruh warga sekolah harus mampu mewujudkan keinginan tersebut. Dalam penelitian ini siswa sebagai responden dapat menunjukkan partisipasi yang aktif baik dalam aspek keterlibatan terhadap kebersihan lingkungan, tanggung jawab dalam kebersihan lingkungan maupun kontribusi dalam kebersihan lingkungan. Untuk lebih jelasnya dapat dilihat pada tabel 4 di bawah ini.

Tabel 4. Partisipasi Siswa Dalam

Kebersihan Lingkungan Sekolah ( Pertanyaan Positif )

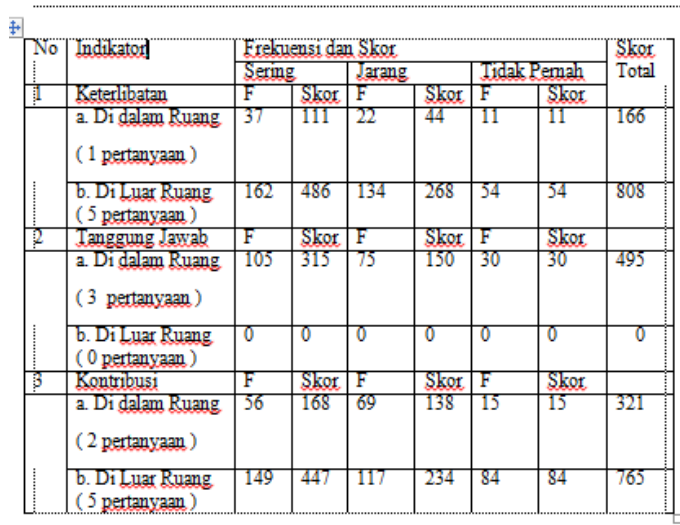

Berdasarkan tabel tersebut di atas, padaindikator Keterlibatan siswa di dalam ruang kelas terkait dengan kebersihan lingkunganmenujukkan bahwa sebesar $66,87 \%$ sering terlibat, $26,50 \%$ jarang terlibat dan hanya 6,63 
$\%$ tidak pernah terlibat dalam kegiatan kebersihan lingkungan. Dengan demikian sebagian besar responden memiliki keterlibatan dalam kebersihan lingkungan di dalam ruang sekolah. Artinya bahwa siswa sering mengingatkan temannya agar membuang sampah sesuai tempat dan jenisnya dan tidak membiarkan teman membuang sampah sembarangan, serta peduli pada penghijauan kelas melalui pot.

Selanjutnya pada indikator Keterlibatan dalam kebersihan lingkungan di luar ruang kelas siswa sering melakukan kegiatan sebesar $60,15 \%$, jarang sebesar $33,17 \%$, dan tidak pernah terlibat sebesar 6,68 $\%$.Dengan demikian sebagian besar responden memiliki keterlibatan dalam kebersihan lingkungan di luar ruang sekolah. Artinya bahwasiswa sering menghadiri rapat dan menjadi panitia untuk kegiatan yang bertemakan kebersihan, penghijauan, dan peduli lingkungan.

Pada indikator Tanggung Jawab di dalam ruang kelas siswa sering berpartisipasi sebesar $63,14 \%$, jarang berpartisipasi $30,30 \%$, dan tidak pernah berpartisipasi sebesar 6,06\%. Artinya sebagian besar siswa berpartisipasi dalam tugas piket kelas, ikut menjaga kelas agar rapih dan bersih serta berpartisipasi dalam membersihkan limbah setelah praktikum.

Pada indikator Kontribusi untuk kelas, siswa sering berpartisipasi sebesar 52,33\%, jarang berpartisipasi 43,00\%, dan tidak pernah berpartisipasi 4,67\%. Artinya sebagian besar siswa berpartisipasi untuk memberikan kontribusi dalam bentuk menyumbang alat-alat untuk kebersihan lingkungan dan juga membuat majalah dinding tentang lingkungan hidup khususnya tentang kebersihan lingkungan.

Sedangkan indikator Kontribusi untuk di luar kelas, siswa sering berpartisipasi sebesar 58,44\%, jarang berpartisipasi $30,58 \%$, dan tidak pernah berpartisipasi sebesar 10,98\%. Artinya sebagian besar siswa berpartisipasi untuk memberikan kontribusi dalam bentuk memberikan sumbangan ketika ada kegiatan tentang lingkungan hidup, merancang lomba karya ilmiah tentang lingkungan hidup, membuat program kreatif mendaur ulang sampah, serta ikut berpartisipasi dalam mensosialisasikan program-program kebersihan lingkungan.

Tabel 5. Partisipasi Siswa Dalam

Kebersihan Lingkungan Sekolah (Pertanyaan Negatif) 


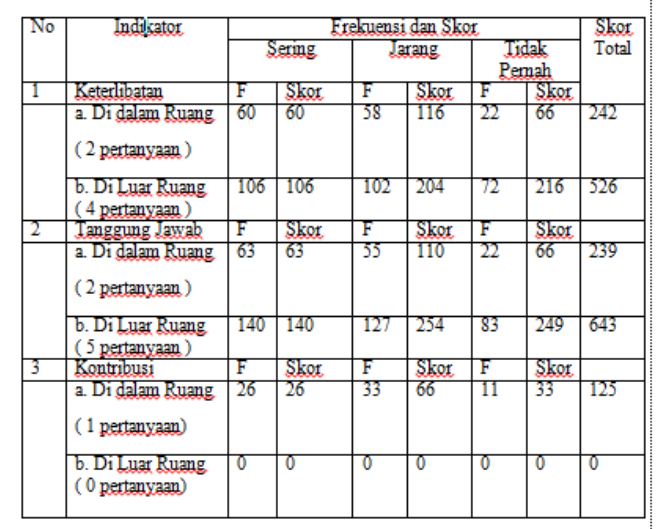

Berdasarkan tabel tersebut di atas, pada indikator Keterlibatan siswa di dalam ruang kelas terkait dengan kebersihan lingkungan menujukkan bahwa sebesar $24,79 \%$ sering terlibat, $47,93 \%$ jarang terlibat dan $27,28 \%$ tidak pernah terlibat dalam kegiatan kebersihan lingkungan. Dengan demikian sebagian besar responden jarang memiliki keterlibatan dalam kebersihan lingkungan di dalam ruang kelas . Artinya bahwa siswa tidakmembiarkan teman membuang sampah sembarangan di kelasdan tidakmembiarkan tanaman layu dan mati pada pot-pot di sekolah

Selanjutnya pada indikator Keterlibatan dalam kebersihan lingkungan di luar ruang kelas siswa sering melakukan kegiatan sebesar $20,15 \%$, jarang sebesar $38,78 \%$, dan tidak pernah terlibat sebesar 41,06 $\%$.Dengan demikian sebagian kecilrespondentidak hadir ketika diajak rapat untuk kegiatan kesiswaan tentang kebersihan lingkungan, membiarkan teman ketika merokok di lingkungan sekolah,tidak peduli terhadap kegiatan lomba kebersihan, dan menolak memberikan sumbangan untuk pembelian alat-alat kebersihan sekolah.

Pada indikator Tanggung Jawab di dalam ruang kelas siswa sering berpartisipasi sebesar 26,37\%, jarang berpartisipasi 46,01\%, dan tidak pernah berpartisipasi sebesar 27,62\%.Artinya sebagian besar siswa jarang tidak membiarkan debu melekat pada ruang kelas, dan jarang tidak membiarkaan limbah praktikum berserakan.

Pada indikator Tanggung Jawab di luar ruang kelas siswa sering berpartisipasi sebesar 21,78 \%, jarang berpartisipasi $39,50 \%$, dan tidak pernah berpartisipasi sebesar 38,72\%.Artinya sebagian besar siswa jarang mendukung program kebersihan lingkungan, jarang tidak membiarkan kamar mandi bersih dan bau, serta jarang tidak parkir motor tidak pada tempatnya.

Pada indikator Kontribusi untuk di dalam kelas, siswa sering berpartisipasi sebesar 20,80\%, jarang berpartisipasi $52,80 \%$, dan tidak pernah berpartisipasi 26,40 \%.Artinya sebagian besar siswa jarang tidak proaktif terhadap kebersihan lingkungan.

\begin{tabular}{|l|l|l|l|}
\hline Volume XVII & Nomor 02 & September 2016 & ISSN 1411-1829 \\
\hline
\end{tabular}




\section{Pengujian Hipotesis}

\section{(1) Pengujian Hipotesis Pertama}

H1: Terdapat hubungan antara Pengetahuan Pelestarian Lingkungan dengan Partisipasi Siswa dalam Kebersihan Lingkungan sekolah.

\section{a. Korelasi Sederhana}

Tabel 6.Korelasi Sederhana $\mathrm{X}_{1}-\mathrm{Y}$

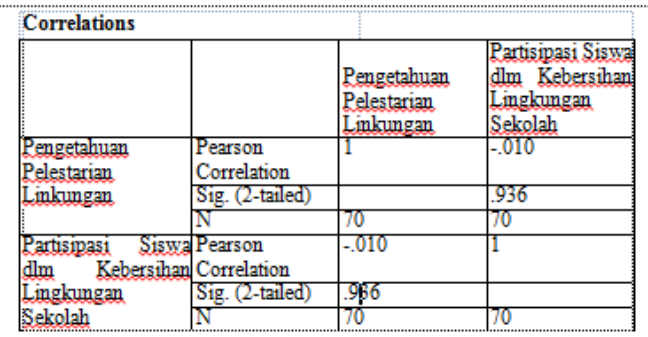

Sumber : Data diolah dengan program SPSS 17,0

Berdasarkan hasil pengolahan SPSS dapat diketahui nilai koefisien korelasi antara Pengetahuan Pelestarian Linkungan denganPartisipasi Siswa dalam Kebersihan Lingkungan Sekolah sebesar - 0,010 ini menunjukkan tidak adanya hubungan yang positif, antara Pengetahuan Pelestarian Lingkungan dengan Partisipasi Siswa dalam Kebersihan Lingkungan Sekolah.

\section{b. Uji Signifikansi Korelasi}

\section{Sederhana}

$\mathrm{H}_{\mathrm{o}}: \rho=0$ (tidak terdapat hubungan yang signifikan antara Pengetahuan Pelestarian Lingkungan dengan Partisipasi Siswa dlm Kebersihan Lingkungan Sekolah.)

$\mathrm{H}_{\mathrm{a}}: \rho \neq 0$ (terdapat hubungan yang signifikan antara Pengetahuan Pelestarian Lingkungan dengan Partisipasi Siswa dlm Kebersihan Lingkungan Sekolah.)

\section{c) Regresi Linier Sederhana}

Tabel 7. Koefisien Regresi Linier Sederhana $\mathrm{X}_{1}-\mathrm{Y}$

\begin{tabular}{|c|c|c|c|c|c|c|c|}
\hline \multicolumn{8}{|c|}{ Coefficients" } \\
\hline \multirow{2}{*}{\multicolumn{2}{|c|}{ Model }} & \multirow{2}{*}{\multicolumn{2}{|c|}{ 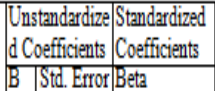 }} & \multirow{3}{*}{13.565} & \multirow[b]{2}{*}{ Sig. } & \multicolumn{2}{|l|}{$\begin{array}{l}\text { Collimearity } \\
\text { Statistics }\end{array}$} \\
\hline & & & & & & Tolerance & TVIF \\
\hline 1 & (Constant) & $\begin{array}{l}67.4 .969 \\
397\end{array}$ & & & .000 & & \\
\hline & $\begin{array}{l}\text { Pengetahuan } \\
\text { Pelestarian } \\
\text { Linlyngan }\end{array}$ & \begin{tabular}{|l|l}
.01 & .195 \\
6 & \\
\end{tabular} & -.010 & .080 & 936 & 1.000 & 1.000 \\
\hline & $\begin{array}{l}\text { adent } \\
\text { a Linghy }\end{array}$ & $\begin{array}{l}\text { le: Pattis } \\
\text { Selopolah }\end{array}$ & Siswa & & & & \\
\hline
\end{tabular}

Sumber : Data diolah dengan program SPSS 17,0

Maka dapat disimpulkan bahwa persamaan regresi linear sederhana sebagai berikut :

$$
\hat{Y}=67.397+(-0.016)+\varepsilon
$$


Konstanta a sebesar 67,397 menyatakan bahwa jika nilai Pengetahuan pelestarian lingkungan konstan (0), maka partisipasi siswa dalam kebersihan lingkungan sebesar 67,397 satuan.

Koefisien b sebesar -0.016 menyatakan bahwa setiap kenaikan satu satuan pengetahuan Pelestarian Lingkungan akan menaikkan Partisipasi Siswa dlm Kebersihan Lingkungan Sekolah sebesar -0,016 satuan

d) Uji Signifikansi Regresi Linier Sederhana

Perumusan hipotesis

$\mathrm{H}_{\mathrm{o}}: \beta=0$ (ada pengaruh yang signifikan antara Pengetahuan Pelestarian Lingkungan akan menaikkan Partisipasi Siswa dlm Kebersihan Lingkungan Sekolah)

$\mathrm{H}_{\mathrm{a}}: \beta \neq 0$ (tidah ada pengaruh yang signifikan antara pengetahuan Pelestarian Lingkungan akan menaikkan Partisipasi Siswa $\mathrm{dlm}$ Kebersihan Lingkungan Sekolah)

Signifikan jika $t_{\text {hitung }}>t_{\text {tabel }}$; atau $\mathrm{t}_{\text {hitung }}<-\mathrm{t}_{\text {tabel }}: \mathrm{H}_{\mathrm{o}}$ ditolak

Dengan asumsi $\mathrm{t}_{\text {tabel }}: \mathrm{t}_{\alpha / 2 ; \mathrm{n}-2}$
Tabel 8. Uji Signifikansi Regresi linier Sederhana $\mathrm{X}_{1}-\mathrm{Y}$

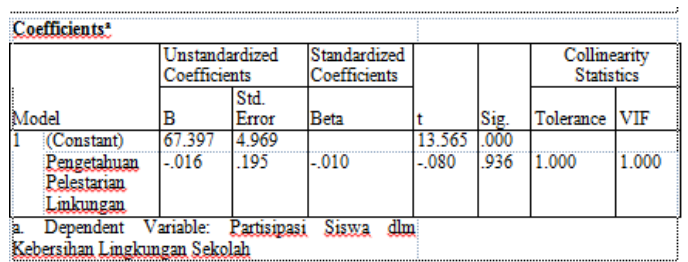

Sumber: Data diolah dengan program SPSS 17,0

Statistik uji :

$$
\begin{aligned}
& t_{\mathrm{O}}=0,08 \mathrm{C} \\
& t_{0,02 ; 68}=1,99
\end{aligned}
$$

Berdasarkan perhitungan diatas didapat nilai $t_{\text {hitung }}$ sebesar - 0,080 nilai ini selanjutnya dibandingkan dengan nilai dari $t_{\text {tabelsebesar }} 1,990$. Dari perbandingan tersebut dapat dilihat bahwa nilai dari $t_{\text {hitung }}$ sebesar 0,080 lebih kecil dari nilai $t_{\text {tabel }}$ sebesar 1,990, maka dapat diambil kesimpulan bahwa Ha ditolak dan Ho diterima yang berarti antara Pengetahuan Pelestarian Lingkungan dan Partisipasi Siswa dalam Kebersihan Lingkungan Sekolah memiliki pengaruh signifikan.

\section{(e) Koefisien Determinasi}

\begin{tabular}{|c|c|c|c|c|c|c|}
\hline \multicolumn{7}{|c|}{ Model Summary ${ }^{b}$} \\
\hline Model & R & R Square & $\begin{array}{c}\text { Adjusted R } \\
\text { Square }\end{array}$ & $\begin{array}{l}\text { Std. Error of the } \\
\text { Estimate }\end{array}$ & & $\begin{array}{l}\text { urbin- } \\
\text { Vatson }\end{array}$ \\
\hline & $.010^{2}$ & .000 & .015 & 12.103 & 2.00 & \\
\hline \multicolumn{6}{|c|}{$\begin{array}{l}\text { 2. Predictors: (Constant), Pengetahuan Pelestarian Linkungan } \\
\text { b. Dependent Variable: Partisipasi Siswa dlm Kebersihan Lingkungan } \\
\text { Sekolah }\end{array}$} & \\
\hline
\end{tabular}

Tabel 9. Koefisien Determinasi $\mathrm{X}_{1}-\mathrm{Y}$ 
Sumber: Data diolah dengan program SPSS 17,0

$$
\mathrm{KD}=0,010^{2} \times 100 \%=0,01 \%
$$

Koefisien determinasi sebesar $0,01 \%$ artinya bahwa Partisipasi Siswa dalam Kebersihan Lingkungan Sekolah dipengaruhi oleh Pengetahuan Pelestarian Lingkungansebesar $0,01 \%$ sedangkan sisanya sebesar 99,9 \% dipengaruhi oleh faktor lain.

\section{Pengujian Hipotesis Kedua}

H2 : Terdapat pengaruh Intensi siswa terhadap output sekolah terhadap Partisipasi siswa dalam kebersihan lingkungan sekolah.

Langkah Pengujian

\section{a) Korelasi Sederhana}

Tabel 10. Korelasi sederhana X2 - Y

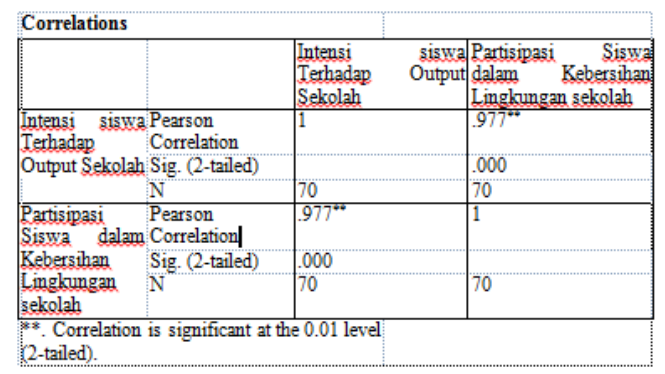

Sumber: Data diolah dengan program SPSS 17,0

Berdasarkan hasil pengolahan SPSS dapat diketahui nilai koefisien korelasi antara intensi siswa terhadap output sekolah dengan partisipasi siswa dalam kebersihan lingkungan sekolah sebesar 0,1 ini menunjukkan adanya hubungan yang positif lemah antara antara intensi siswa terhadap output sekolah dengan partisipasi siswa dalam kebersihan lingkungan sekolah.

\section{b) Uji Signifikansi Korelasi}

\section{Sederhana}

Perumusan hipotesis:

$$
\mathrm{H}_{\mathrm{o}}: \rho=0 \text { (tidak terdapat }
$$
hubungan yang signifikan antara intensi siswa terhadap output sekolah dengan partisipasi siswa dalam kebersihan lingkungan sekolah)

$$
\mathrm{H}_{\mathrm{a}}: \rho \neq 0 \text { (terdapat hubungan }
$$
yang signifikan antara intensi siswa terhadap output sekolah dengan partisipasi siswa dalam kebersihan lingkungan sekolah)

Signifikan jika $t_{\text {hitung }}>t_{\text {tabel }}$; atau $-t_{\text {hitung }}<-t_{\text {tabel }}: H_{o}$ ditolak dengan asumsi $\mathrm{t}_{\text {tabel }}: \mathrm{t}_{\alpha / 2 ; \mathrm{n}-2}$

Statistik uji :

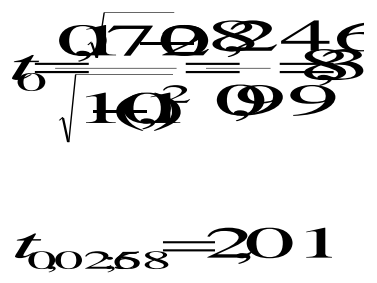


Berdasarkan perhitungan diatas didapat nilai $\mathrm{t}_{\text {hitung }}$ sebesar 8,329 nilai ini selanjutnya dibandingkan dengan nilai dari $t_{\text {tabel }}$ sebesar 2,011. Dari perbandingan tersebut dapat dilihat bahwa nilai dari $t_{\text {hitung }}$ sebesar 8,329 lebih besar dari nilai $t_{\text {tabel }}$ sebesar 2,011, maka dapat diambil kesimpulan bahwa $\mathrm{H}_{\mathrm{o}}$ ditolak dan $\mathrm{H}_{\mathrm{a}}$ diterima, yang berarti antara intensi siswa terhadap output sekolah dengan partisipasi siswa dalam kebersihan lingkungan sekolah memiliki hubungan yang signifikan.

c) Regresi Linier Sederhana

Tabel 11. Koefisien Regresi Linier Sederhana $\mathrm{X}_{2}-\mathrm{Y}$

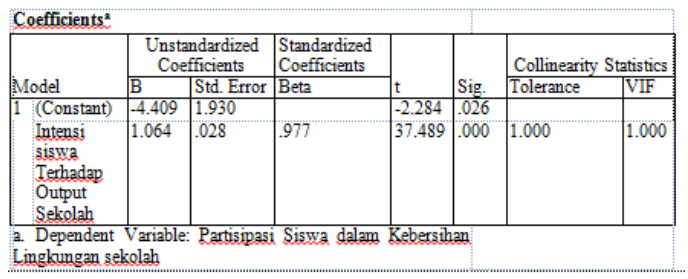

Sumber: Data diolah dengan program SPSS 17,0

Maka dapat disimpulkan bahwa persamaan regresi linear sederhana sebagai berikut :

$$
\hat{Y}=-4.409+1.064 X_{2}+\varepsilon
$$

Konstanta a sebesar $\quad-4,409$ menyatakan bahwa jika nilai intensi siswa terhadap output sekolah konstan
(0), maka partisipasi siswa dalam kebersihan lingkungan sebesar $-4,409$ satuan.

$\begin{array}{ccr}\text { Koefisien } & \text { b } & \text { sebesar } \\ 1,064 \text { menyatakan } & \text { bahwa } & \text { setiap }\end{array}$ kenaikan satu- satuan antara intensi siswa terhadap output sekolah dengan partisipasi siswa dalam kebersihan lingkungan sebesar 1,064 .

d) Uji Signifikansi Regresi Linier Sederhana

Perumusan hipotesis

$\mathrm{H}_{\mathrm{o}}: \beta=0$ (tidak ada pengaruh yang signifikan antara antara intense siswa terhadap output sekolah dengan partisipasi siswa dalam kebersihan lingkungan)

$\mathrm{H}_{\mathrm{a}}: \beta \neq 0$ (ada pengaruh yang signifikan antara antara intense siswa terhadap output sekolah dengan partisipasi siswa dalam kebersihan lingkungan)

Signifikan jika $t_{\text {hitung }}>t_{\text {tabel }}$; atau $-\mathrm{t}_{\text {hitung }}<-\mathrm{t}_{\text {tabel }}: \mathrm{H}_{\mathrm{o}}$ ditolak dengan asumsi $\mathrm{t}_{\text {tabel }}: \mathrm{t}_{\alpha / 2 ; \mathrm{n}-2}$

Tabel 12. Uji Signifikansi Regresi Linier Sederhana $\mathrm{X}_{2}-\mathrm{Y}$ 


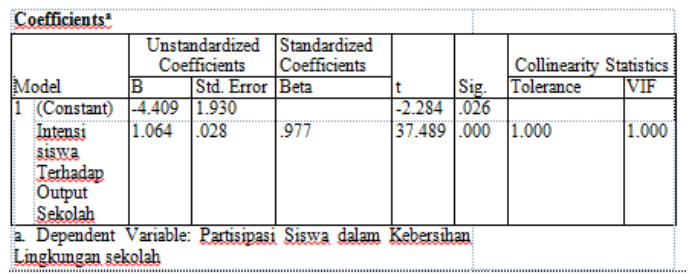

Sumber: Data diolah dengan program SPSS 17,0

Statistik uji

$$
\begin{aligned}
& t_{0}=3748 ! \\
& t_{00268}=201
\end{aligned}
$$

Berdasarkan perhitungan diatas didapat nilai $t_{\text {hitung }}$ sebesar 37,489 nilai ini selanjutnya dibandingkan dengan nilai dari $t_{\text {tabel }}$ sebesar 2,011. Dari perbandingan tersebut dapat dilihat bahwa nilai dari $t_{\text {hitungsebesar }}$ 37,489lebih besar dari nilai $t_{\text {tabel }}$ sebesar 2,011, maka dapat diambil kesimpulan bahwa $\mathrm{H}_{\mathrm{o}}$ ditolak, dan $\mathrm{H}_{\mathrm{a}}$ diterima, yang berarti antara intensi siswa terhadap output sekolah dengan partisipasi siswa dalam kebersihan lingkungan memiliki pengaruh signifikan.

d) Koefisien Determinasi

\begin{tabular}{|c|c|c|c|c|c|}
\hline \multicolumn{5}{|c|}{ Model Summary } & \multirow[b]{2}{*}{$\begin{array}{l}\text { Durbin- } \\
\text { Watson }\end{array}$} \\
\hline Model & $\mathrm{R}$ & R Square & $\begin{array}{l}\text { Adjusted } \\
\text { R Square }\end{array}$ & $\begin{array}{l}\text { Std. Error of the } \\
\text { Estimate }\end{array}$ & \\
\hline 1 & $.977^{\mathrm{a}}$ & 954 & .953 & 2.600 & 2.172 \\
\hline \multicolumn{6}{|c|}{$\begin{array}{l}\text { a. Predictors: (Constant), Intensi siswa Terhadap Output } \\
\text { Sekolah } \\
\text { b. Dependent Variable: Partisipasi Siswa dalam Kebersihan } \\
\text { Linglungan sekolah }\end{array}$} \\
\hline
\end{tabular}

Tabel 13. Koefisien Determinasi $\mathrm{X}_{2}-\mathrm{Y}$
Sumber: Data diolah dengan program SPSS 17,0

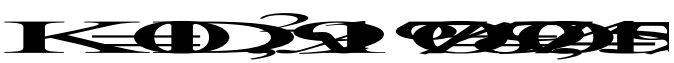

Koefisien determinasi sebesar 95,45\% artinya bahwa Partisipasi Siswa dalam Kebersihan Lingkungan sekolah dipengaruhi oleh Intensi Siswa terhadap Output Sekolah sebesar 95,45\% sedangkan sisanya sebesar $4,55 \%$ dipengaruhi oleh faktor lain.

\section{Pengujian Hipotesis Ketiga}

H3 : Ada pengaruh Intensi Siswa terhadap Output Sekolah, Pengetahuan Pelestarian Lingkungan secara bersamasama terhadap Partisipasi Siswa dalam Kebersihan Lingkungan sekolah.

a) Korelasi Berganda

Tabel14. Korelasi Berganda $\mathrm{X}_{1} \mathrm{X}_{2}-\mathrm{Y}$

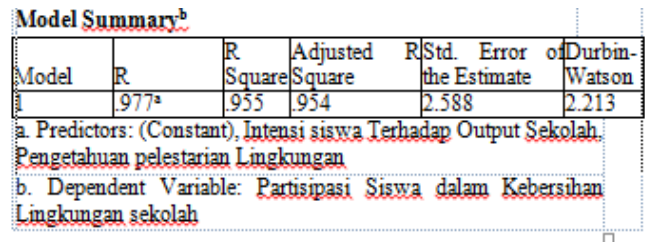


Sumber: Data diolah dengan program SPSS 17,0

Berdasarkan hasil pengolahan SPSS dapat diketahui nilai koefisien korelasi antara Intensi Siswa terhadap Output Sekolah, Pengetahuan Pelestarian Lingkungan dengan Partisipasi Siswa dalam Kebersihan Lingkungan Sekolah sebesar 0,977 ini menunjukkan adanya tingkat hubungan yang positif kuat antara Intensi siswa Terhadap Output Sekolah, Pengetahuan pelestarian Lingkungan dengan Partisipasi Siswa dalam Kebersihan Lingkungan sekolah

Uji Signifikansi Korelasi Berganda

Perumusan hipotesis

$\mathrm{H}_{\mathrm{o}}: \rho=0$ (tidak ada hubungan yang signifikan antara Intensi Siswa terhadap Output Sekolah, Pengetahuan Pelestarian Lingkungan dengan Partisipasi Siswa dalam Kebersihan Lingkungan sekolah)

$\mathrm{H}_{\mathrm{a}}: \rho \neq 0$ (ada hubungan yang signifikan antara Intensi Siswa terhadap Output Sekolah, Pengetahuan Pelestarian Lingkungan dengan Partisipasi Siswa dalam Kebersihan Lingkungan sekolah)

Signifikan jika $F_{\text {hitung }}>F_{\text {tabel }}: H_{o}$ ditolak
Dengan asumsi $\mathrm{F}_{\text {tabel }}: \mathrm{F}_{\alpha ; \mathrm{k} ; \mathrm{n}-\mathrm{k}-1}$

Statistik uji:

$$
F_{o}=\frac{0,977^{2} / 2}{\left(1-0,977^{2}\right) /(70-2-1)}=\frac{0,4772}{0,0454}=10,51
$$

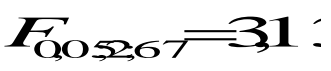

Berdasarkan perhitungan diatas didapat nilai $F_{\text {hitung }}$ sebesar 10, 51 nilai ini selanjutnya dibandingkan dengan nilai dari $F_{\text {tabel }}$ sebesar 3, 13. Dari perbandingan tersebut dapat dilihat bahwa nilai dari $F_{\text {hitung }}$ 10,51 lebih besar dari nilai $\mathrm{F}_{\text {tabel }}$ sebesar 3,13 maka dapat diambil kesimpulan bahwa $\mathrm{H}_{\mathrm{o}}$ ditolak dan $\mathrm{H}_{\mathrm{a}}$ diterima, jadi antara Intensi Siswa terhadap Output Sekolah, Pengetahuan Pelestarian Lingkungan dengan Partisipasi Siswa dalam Kebersihan Lingkungan sekolah memiliki hubungan signifikan.

\section{c) Regresi Linier Berganda}

Tabel 15. Koefisien Regresi Linier Berganda $\mathrm{X} 1 \mathrm{X}_{2}-\mathrm{Y}$

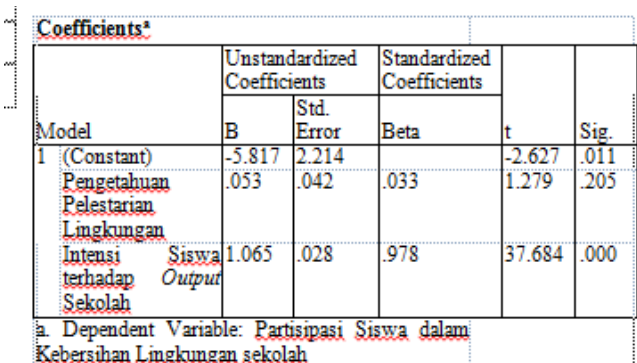


Sumber: Data diolah dengan program SPSS 17,0

Maka dapat disimpulkan bahwa persamaan regresi linear berganda sebagai berikut :

$$
\begin{gathered}
\hat{\mathrm{Y}}=-5,817+0,053 \mathrm{X}_{1}+ \\
1,065 \mathrm{X}_{2}+\varepsilon
\end{gathered}
$$

Konstanta a sebesar $\quad-5,817$ menyatakan bahwa jika nilai Pengetahuan pelestarian lingkungan dan intensi siswa terhadap output sekolah konstan (0), maka nilai partisipasi siswa dalam kebersihan lingkungan sekolah sebesar $-5,817$.

Koefisien $\quad b_{1}$ sebesar 0,053 menyatakan bahwa setiap kenaikan satu satuan Pengetahuan pelestarian lingkungan akan menaikan partisipasi siswa dalam kebersihan lingkungan sekolahsebesar 0,053.

Koefisien $b_{2}$ sebesar 1,065 menyatakan bahwa setiap kenaikan satu satuan intensi siswa terhadap output sekolah akan menaikkan partisipasi siswa dalam kebersihan lingkungan sekolah sebesar 1,065.

\section{d) Uji Signifikansi Regresi Linier Berganda}

Perumusan hipotesis:
$\mathrm{H}_{\mathrm{o}}: \beta_{1}=\beta_{2}=0$ (tidak terdapat pengaruh yang signifikan antara Pengetahuan Pelestarian Lingkungan, Intensi Siswa terhadap Output Sekolahdengan Partisipasi Siswa dalam Kebersihan Lingkungan Sekolah)

$\mathrm{H}_{\mathrm{a}}: \beta_{1} \neq \beta_{2} \neq 0$ (terdapat pengaruh yang signifikan antara Pengetahuan Pelestarian Lingkungan, Intensi Siswa terhadap Output Sekolahdengan Partisipasi Siswa dalam Kebersihan Lingkungan Sekolah)

Signifikan jika $F_{\text {hitung }}>F_{\text {tabel }}: H_{o}$ ditolak

Dengan asumsi $\mathrm{F}_{\text {tabel }}: \mathrm{F}_{\alpha ; \mathrm{k} ; \mathrm{n}-\mathrm{k}-1}$

Tabel 16. Uji Signifikansi Regresi Linier Berganda $\mathrm{X}_{1} \mathrm{X}_{2}-\mathrm{Y}$

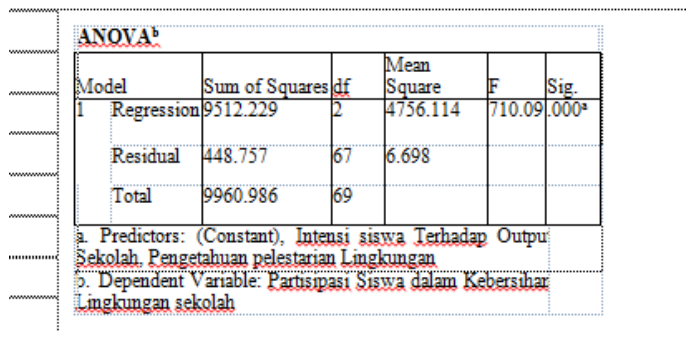

Sumber : Data diolah dengan program SPSS 17,0

$$
F_{0}=\frac{9512,229 /(2-1)}{448,757 /(70-2)}=\frac{9512,229}{6,599}=1441,465 \text { । }
$$


Berdasarkan perhitungan diatas didapat nilai $F_{\text {hitung }}$ sebesar 1441,465 nilai ini selanjutnya dibandingkan dengan nilai dari $\mathrm{F}_{\text {tabel }}$ sebesar 3,13. Dari perbandingan tersebut dapat dilihat bahwa nilai dari $F_{\text {hitung }}$ sebesar 1441,465 lebih besar dari nilai $F_{\text {tabel }}$ sebesar 3,13, maka dapat diambil kesimpulan bahwa $\mathrm{H}_{\mathrm{o}}$ ditolak dan $\mathrm{H}_{\mathrm{a}}$ diterima, yang berarti antara Pengetahuan Pelestarian Lingkungan, Intensi Siswa terhadap Output Sekolah dengan Partisipasi Siswa dalam Kebersihan Lingkungan Sekolah memiliki pengaruh signifikan.

e) Koefisien Determinasi

Tabel 17. Koefisien Determinasi $X_{1} X_{2}$

$$
-\mathrm{Y}
$$

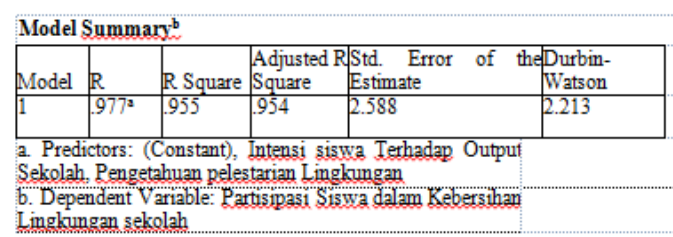

Sumber : Data diolah dengan program SPSS 17,0

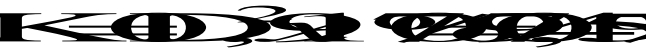

Koefisien Determinasi sebesar 95,45\% artinya bahwa Partisipasi
Siswa dalam Kebersihan Lingkungan Sekolah dipengaruhi oleh Intensi siswa Terhadap Output Sekolah dan Pengetahuan Pelestarian Lingkungansebesar $\quad 95,45 \quad \%$ sedangkan sisanya sebesar 4,55\% dipengaruhi oleh faktor lain.

\section{KESIMPULAN}

1. Sebagian besar siswa mampu memahami konsep, fakta, dan prosedural yang terkait dengan pelestarian lingkungan hidup.

2. Sebagian besar siswa (responden) memiliki intensi yang kuat terhadap kegiatan-kegiatan akademik dan non akademik (output sekolah) berdasarkan sikap yang dimilikinya, dukungan yang diterimanya dan fasilitas yang dapat meningkatkan prestasi baik akademik maupun non-akademiknya.

5. Sebagian besar siswa memiliki keterlibatan, tanggung jawab dan kontribusi dalam berpartisipasi terhadap kebersihan lingkungan di sekolahnya.

6. Hubungan antara Pengetahuan Pelestarian Lingkungan dengan Partisipasi Siswa dalam Kebersihan Lingkungan menunjukkan hubungan yang negatif. 
7. Hubungan antara Intensi Siswa terhadap Output Sekolah dengan Partisipasi Siswa dalam Kebersihan Lingkungan menunjukkan hubungan yang positif.

8. Hubungan antara Pengetahuan Pelestarian Lingkungan dan Intensi Siswa terhadap Output Sekolah secara bersama-sama dengan Partisipasi Siswa dalam Kebersihan Lingkungan menunjukkan hubungan yang positif.

\section{DAFTAR PUSTAKA}

Ajzen, Icek dan Fishbein, Martin. Understanding Attitudes and Predicting Social Behavior, Prentice-Hall, Englewood Scliffs, NJ, 1980.

Ajzen,Icek dan Fishbein Martin. From Intentions to Actions .Attitudes, Personality, and Behavior. London, England : Open University Press.1988.

Azjen, Icek.The Theory of Planned Behavior, Organizational Behavior and Human Decision Processes, 1991.

Ajzen, I. \& Fishbein M. Attitudes and the attitude - Behavior Relation : Reasoned and automatic processes. In W. Stroebe \& M. Hewstone (Eds), European Review of Social Psychology, John Wiley \& Sons, 2000.

Ajzen, Icek, Attitudes, Personality, and Behavior, Edisi kedua, New York: Open University Press.2005.
Arianto, Ismail. Pendidikan Kependudukan dan Lingkungan Hidup Untuk IKIP dan FKIP. Jakarta: Dirjen Dikdasmen.1988.

Arikunto, Suharsini. Prosedur Penelitian Suatu Pendekatan Praktik, Edisi Revisi V. Jakarta : PT Rineka Cipta, 2002.

Azwar, Saifudin. Sikap Manusia dan Teori

Pengukurannya. Yogyakarta: Pustaka Pelajar, 1995.

Sikap Manusia dan Teori Pengukurannya. Yogyakarta:Pustaka Pelajar.

Barker, R. G. Prospecting in environmental psychology: Oskaloosa Revisited. Dalam D. Stokols, \& I. Altman (Eds.), Handbook of EnvironmentalPsychology, Vol. 2. New York: Wiley, 1987.

B. Kar, Snehendu. Health Promotion Indicator and Action. New York: Springer Publishing Company, 1989.

Canter, D. Intention, meaning and structure: Social action in its physical context. Makalah dalamseminar: Manusia, Rumah dan Lingkungan, FakultasPsikologi UI, Bagian Psikologi Sosial dan Fakultas Teknik UI, Jurusan Arsitektur, Depok, 1986.

Chaplin, J.P., Kamus Lengkap Psikologi, cet. ke-9, Penerjemah: Dr. Kartini Kartono, Jakarta: Rajawali Pers. 2004

Daldjoeni, N. Geografi Baru : Organisasi Keruangan Dalam Teori dan Praktek. Bandung : Alumni, 1997.

David C, McClelland. Human Motivation. CUP Archive, 1987. 
Dwi Susilo, Rachmad K. Sosiologi Lingkungan. Jakarta: Rajagrafindo Persada, 2008.

Echols, John M., \& Hassan Shadily, Kamus Inggris Indonesia, cet. ke-25, Jakarta: Gramedia.2000.

Faisal, Sanapiah.. Dasar dan Teknik Menyusun Angket. Surabaya: UsahaNasional.1981.

Fishbein, Martin, \& Icek Ajzen, Belief, Attitude, Intention, dan Behavior: An Introduction to Theory and Research, Massachusetts: Addison-Wesley Publishing Company.1975.

Gochman, David S. Handbook of Health Behavior Research: Relevance for Professionals and Issues for the Future. Springer, 1997.

Glaser, B. G., \& Strauss, A. L. The discovery of grounded theory: Strategies for qualtitative research. New York: Aldine, 1967.

Hines, J. M., Hongerford, H. R., \& Tomera, A. N. (Analysis and synthesis of research on responsible environmental behavior: A meta-analysis. Journal of Environmental Education. Vol. 18 (2), 1-8, 1986.

Hardjosumantri K.Hukum Tata Lingkungan.UGM

Press.Yogyakarta.1983.

Irwan, Zoer'aini Djamal. Prinsip-prinsip Ekologi dan Organisasi Ekosistem Komunitas dan Lingkungan. Jakarta : Bumi Aksara, 2003.

Lewin. K, Field Theory in Social Science: Selected Theoretical Papers, New York Harper, 1951.
Mappiare, Andi. Psikologi Remaja, Surabaya: Usaha Nasional Surabaya, 1982.

Mathieson, K. Predicting User Intentions: Comparing the Technology Acceptance Model with the Theory of Planned Behavior, dalam Information Research, Vol. 2, No. 3. 1991.

Mardikanto, Totok. Komunikasi Pembangunan. Surakarta: UNS Press, 2010.

Notoatmodjo, Soekidjo. Promosi Kesehatan: Teori dan Aplikasi, Jakarta: Rineka Cipta, 2005.

Notoatmodjo, Soekidjo, \& Sarwono, Solita.. Pengantar Ilmu Perilaku Kesehatan. Jakarta: Badan Penerbit Kesehatan Masyarakat Fakultas Kesehatan Masyarakat Universitas Indonesia, 1985.

Notoatmodjo, Soekidjo. Prinsip-prinsip dasar ilmu kesehatan masyarakat. Cet. Ke- 2, Mei. Jakarta: Rineka Cipta, 2003.

Notoatmodjo, Soekidjo. Promosi Kesehatan dan Ilmu Perilaku. Jakarta: Rineka Cipta, 2007.

Nursid, Sumaatmadja. Studi Geografi Suatu Pendekatan dan Analisa Keruangan. Bandung: Alumni, 1988.

Orams, Mark.Creating effective interpretation for managing interaction between tourists and wildlife, Australian Journal of Environtmental Education, vol. 10, September, 1994.

Pedoman Pengelolaan Promosi Kesehatan dalam Pencapaian Perilaku Hidup Bersih dan Sehat. Jakarta: Departemen Kesehatan Republik Indonesia, Pusat Promosi Kesehatan.2008.

Prawiro, Ruslan H. Ekologi Lingkungan Pencemaran : Memperkenalkan 
Seluk Beluk Lingkungan dan Masalahnya dan Cara mengatasinya. Penerbit Satyawacana, 1983.

Prawiroatmodjo, Dendasurono. PKLH dalam Upaya Pembinaan Indonesia Seutuhnya. Pidato Pengukuhan Guru Besar IKIP Jakarta, 14 Juli 1987.

Proshansky, et.al. An introduction to environmental psychology. New York: Holt Rinehartand Wiston, 1974.

Putrawan, I Made. Pengaruh Strategi Penyampaian Materi pada FMIPA dan FPIPS terhadap Hasil Belajar Mahasiswa tentang Konsep-konsep Ekosistem. Jakarta : LPP IKIP Jakarta, 1990.

Salim, Emil. Pembangunan Berwawasan Lingkungan. Jakarta: LP3ES, 1983.

Salim, Emil. Lingkungan Hidup dan Pembangunan.Jakarta: Mutiara.1979.

Sapardi. Lingkungan Hidup dan Kelestariannya.Bandung:

Alumni.1984.

Sarwono, Sarlito Wirawan. Psikologi Remaja. Penerbit Cv. Rajawali, Jakarta. 1991.

Sarwono, Sarlito Wirawan. Psikologi Sosial. Jakarta: Balai Pustaka.2002.

Schoggen, P. F. (1989).Behavior setting: A revision of barber's ecological psychology. Stanford, CA: Stanford University Press, 1989.

Slamet dan Sarjono. Pembangunan Masyarakat Berwawasan Partisipatif. Surakarta: UNS Press, 1994.
Soetrisno, Loekman.Menuju Masyarakat Partisipatif. Yogyakarta: Penerbit Kanisius, 1995.

Soedarmo, Soedjiran Reso. Pengantar Ekologi. Jakarta: FPS-IKIP Bekerjasama dengan BKKBN, 1985.

Soerjani, Moh; Rofiq Ahmad; Rozy Munir. Lingkungan, Sumberdaya Alam dan Kependudukan dalam Pembangunan. Jakarta : Penerbit UI, 1987.

Stokols, D. \& Altman, I. (Eds.) (Handbook of environmental psychology. New York: Wiley, 1987.

Sudjana, Nana. Teeori-teori Belajar untuk Pengajaran. Jakarta : Lembaga Penerbit FEUI, 1997.

Sumaatmadja, Nursid. Studi Geografi Suatu Pendekatan dan Analisa Keruangan. Bandung : Alumni, 1988.

Sumarwoto, Otto. Ekologi, Lingkungan Hidup dan Pembangunan. Jakarta : Djambatan, 1987.

Soemarwoto, Otto. Ekologi LIngkungan Hidup dan Pembangunan. Jakarta : Pustaka Pelajar.1994.

\begin{tabular}{llr} 
& \multicolumn{2}{r}{ Ekologi } \\
LIngkungan & Hidup & dan \\
Pembangunan. & Jakarta & Djambatan.1997.
\end{tabular}

Soerjani. Lingkungan: Sumber Daya Alam dan Kepandudukan Dalam Pembangunan.Jakarta: UI Press. 1987.

Suparmoko, M. Ekonomi Sumberdaya Alam dan Lingkungan: Suatu Pendekatan Teori. Yogyakarta: PAU - Studi Ekonomi UGM, 1989. 
Suriasumantri, Jujun. Pembangunan, Modernisasi dan Pendidikan. Jakarta : LPP IKIP Jakarta, 1988.

Suriasumantri, Jujun. Filsafat IlmuSebuah Pengantar Populer. Jakarta : Penerbit Sinar Harapan, Cetakan kedua.1985.

Suriasumantri, Jujun S. Ilmu dalam Perspektif, Jakarta: Yayasan Obor Indonesia.2001.

Syah, Muhidin. Psikologi Pendidikan dengan Pendekatan Baru. Bandung : Remaja Rosdakarya, 1996.

Tanjung, Shalihuddin Djalal. Dasardasar Ekologi. Yogyakarta: UGM Press.1992.

Taylor, Shelley E. Health Psychology, Seventh Edition. New York: McGraw-Hill Companies, Inc.2009.

Undang-Undang Republik Indonesia No. 20 Tahun 2003 tentang Pendidikan

Undang-Undang Republik Indonesia No. 32 Tahun 2009 tentang Perlindungan dan Pengelolaan Lingkungan Hidup.

Wibowo, I. Faktor-faktor personal dan sosial untuk mempengaruhi intensi kaum ibu dalam pemeliharaan lingkungan. Jakarta: Pusat Penelitian Sumber Daya Manusia dan Lingkungan - LPUI, 1993.

Wardhana, Wisnu Aryo. Dampak Pencemaran Lingkungan.Yogyakarta: Andi Offset.2001.

Walgito, Bimo. Pengantar Psikologi Umum. Yogyakarta: Bina Aksara, 2001. 
